\title{
Hubungan antara Asupan Gizi dengan Kadar Hemoglobin Ibu Hamil
}

\author{
Anggit Kartikasari, Tia Srimulyawati, Indri Siti Maryam \\ Email: Anggit8616@gmail.com \\ Kebidanan Sekolah Tinggi Ilmu Kesehatan Kuningan, Indonesia \\ Jl. Lingkar Kadugede No 2 Kuningan \\ Telp. (0232) 875847
}

\begin{abstract}
Abstrak
Asupan gizi pada saat hamil berpengaruh pada pemenuhan kebutuhan zat besi karena terjadi peningkatan ekspansi massa sel darah merah, maka kebutuhan akan zat besi bertambah dan hal ini akan berdampak pada terjadinya anemia. Angka kejadian anemia pada ibu hamil masih cukup tinggi, berdasarkan Riskesdas (2013) mengatakan terdapat 37,1\% ibu hamil anemia akibat dari kekurangan gizi. Tujuan penelitian ini untuk mengetahui hubungan antara asupan gizi dengan kadar hemoglobin ibu hamil di Wilayah UPTD Puskesmas Ciawigebang Kabupaten. Metode penelitian ini adalah kuantitatif, pengambilan sampel dengan teknik total sampling sampling dengan jumlah $25 \mathrm{ibu}$ hamil. Instrumen yang digunakan menggunakan lembar observasi dan analisis yang digunakan menggunakan Spearman Rank.Berdasarkan hasil penelitian analisis univariat, sebagian besar ibu hamil memiliki asupan gizi sedang yaitu sekitar 68\% (17 orang), sedangkan sebagian besar ibu hamil memiliki kadar $\mathrm{Hb}<11 \mathrm{gr} \%$ atau anemia ringan yaitu sekitar $56 \%$ (14 orang ). Hasil analisis bivariat menunjukkan nilai $(\mathrm{r}=0,411 p=0,041)$ hal ini menunjukan bahwa terdapat hubungan yang signifikan antara asupan gizi dengan kadar $\mathrm{Hb}$ ibu hamil.Disimpulkan bahwa terdapat hubungan yang signifikan antara asupan gizi dengan kadar $\mathrm{Hb}$ ibu hamil. Diharapkan bagi ibu hamil untuk lebih memperhatikan asupan gizi dalam setiap supaya pemenuhan gizi ibu dan janin terpenuhi.
\end{abstract}

Kata Kunci: asupan gizi; kadar $\mathrm{Hb}$; ibu hamil.

\begin{abstract}
Nutritional intake during pregnancy has an effect on fulfilling iron needs because there is an increase in the mass expansion of red blood cells, the need for iron increases and this will have an impact on anemia. The incidence of anemia in pregnant women is still quite high, based on Riskesdas (2013) states that $37.1 \%$ of pregnant women have anemia due to malnutrition. The purpose of this study was to determine the relationship between nutritional intake and hemoglobin levels of pregnant women in the UPTD Ciawigebang District Health Center. This research method is quantitative, sampling with a total sampling technique with a total of 25 pregnant women. The instrument used was the observation sheet and the analysis used the Spearman Rank. Based on the results of the univariate analysis study, most pregnant women had moderate nutritional intake, namely around $68 \%$ (17 people), while most pregnant women had $\mathrm{Hb}$ levels $<11 \mathrm{gr} \%$ or mild anemia, namely around $56 \%$ (14 people). The results of the bivariate analysis showed a value $(\mathrm{r}=$ $0.411 \mathrm{p}=0.041)$, this indicated that there was a significant relationship between nutritional intake and hemoglobin levels of pregnant women. It was concluded that there was a significant relationship between nutritional intake and hemoglobin levels of pregnant women. It is expected for pregnant women to pay more attention to nutritional intake in each so that the fulfillment of mother and fetus nutrition is fulfille
\end{abstract}

Keywords: nutritional intake; Hb levels; pregnant women. 
Jurnal Kebidanan Harapan Ibu Pekalongan

\section{Pendahuluan}

Masa kehamilan
merupakan masa yang sangat
menentukan kualitas sumber daya
manusia di masa depan, karena
tumbuh kembang anak ditentukan
mulai semenjak dalam kandungan.
Asupan gizi pada saat hamil
berpengaruh pada pemenuhan
kebutuhan zat besi karena terjadi
peningkatan ekspansi massa sel
darah merah, maka kebutuhan akan
zat besi bertambah dan hal ini akan
berdampak pada terjadinya anemia.
Kadar Hb selama dalam kehamilan
merupakan hal yang penting karena
protein pembawa oksigen dalam
darah, apabila Hb nya kurang maka
oksigen dalam darah nya pun
kurang sedangkan ibu memerlukan
banyak oksigen untuk ibunya
sendiri dan juga untuk janinnya. Berdasarkan data dari Riskesdas tahun 2013ada 37,1\% ibu hamil mengalami anemia, yaitu ibu hamil dengan kadar $\mathrm{Hb}$ kurang dari $11,0 \mathrm{gr} / \mathrm{dL}$. Kejadian anemia meningkat dilihat dari darta Riskesdas tahun 2018, ibu hamil yang mengalami anemia tahun sebanyak $48,9 \%$, berdasarkan umur ibu hamil yang mengalami anemia paling banyak pada kisaran usia 1524 sebanyak $84,6 \%{ }^{(1)}$

Status gizi ibu hamil dapat dipengaruhi oleh beberapa faktor yaitu, usia ibu, berat badan ibu, suhu lingkungan, pengetahuan ibu hamil dan keluarga tentang gizi, kebiasaan dan pandangan ibu terhadap makanan, aktivitas, status kesehatan, dan juga status ekonomi. Oleh karena itu, dari beberapa faktor tersebut faktor kebiasaan dan pandangan ibu terhadap makanan yaitu pola makannya dan juga status kesehatan ibu yang akan dilihat dari kadar $\mathrm{Hb}$ ibu yang akan diteliti untuk menentukan ada atau tidaknya hubungan dengan status gizi ibu hamil. ${ }^{(2)}$

Berdasarkan data di atas bahwa status gizi bagi ibu hamil masih perlu ditingkatkan lagi supaya bisa menurunkan angka kesakitan dan kematian ibu akibat dari kurangnya gizi terhadap ibu hamil, serta lebih memperhatikan bagaimana status gizi ibu hamil. Maka dari itu penulis merasa tertarik untuk melakukan penelitian tentang hubungan antara asupan gizi dengan kadar hemoglobin ibu hamil di UPTD Puskesmas Ciawigebang Kabupaten Kuningan. Tujuan penelitian ini adalah mengetahui Hubungan Antara Asupan Gizi Dengan Kadar Hemoglobin Ibu Hamil di Wilayah UPTD Puskesmas Ciawigebang Kabupaten Kuningan tahun 2017.

\section{Metode Penelitian}

Metode penelitian ini adalah kuantitatif, populasi dalam penelitian ini adalah ibu hamil primigravida trimester III, pengambilan sampel dengan teknik total sampling sampling dengan jumlah 25 ibu hamil.penelitian mempunyai 2 varianbel. variabel bebas dalam penelitian ini adalah asupan gizi ibu hamil sedangkan variabel terikatnya adalah kadar HB ibu hamil. Instrumen yang digunakan menggunakan lembar observasi . Data yang digunakan dalam penelitian ini adalah data primer dari hasil observasi ibu hamil secara langsung dan analisis yang digunakan menggunakan Spearman Rank.. 
Jurnal Kebidanan Harapan Ibu Pekalongan

\section{Hasil dan Pembahasan}

\section{Hasil penelitian}

Tabel 1. Distribusi Asupan Gizi Ibu Hamil

\begin{tabular}{cccc}
\hline No & $\begin{array}{c}\text { Asupan Gizi Ibu } \\
\text { Hamil Primigravida } \\
\text { Trimester III }\end{array}$ & F & \% \\
\hline 1 & Baik & 7 & $28 \%$ \\
\hline 2 & Sedang & 17 & $68 \%$ \\
\hline 3 & Kurang & 1 & $4 \%$ \\
\hline & Jumlah & $\mathbf{2 5}$ & $\mathbf{1 0 0 \%}$ \\
\hline
\end{tabular}

Berdasarkan Tabel di atas dari 25 responden sebagian besar 17 responden $(72 \%)$ asupan gizinya sedang, 7 responden (28\%) asupan gizi baik dan 1 responden (28\%) asupan gizinya kurang.

Tabel 2. Distribusi Kadar Hb Ibu Hamil

\begin{tabular}{cccc}
\hline No & $\begin{array}{c}\text { Kadar Hb Ibu Hamil } \\
\text { Primigravida } \\
\text { Trimester III }\end{array}$ & F & \% \\
\hline 1 & Normal & 11 & $44 \%$ \\
\hline 2 & Anemia Ringan & 14 & $56 \%$ \\
\hline & Jumlah & $\mathbf{2 5}$ & $\mathbf{1 0 0 \%}$ \\
\hline
\end{tabular}

Berdasarkan Tabel di atas dari 25 responden sebagian besar responden memiliki anemia ringan sebanyak $14 \mathrm{ibu}$ hamil (56 \%) dan ibu hamil yang kadar Hbnya normal terdapat 11 ibu hamil $(44 \%)$.

Tabel 3 Hubungan Antara Asupan Gizi Dengan Kadar Hb Ibu Hamil

\begin{tabular}{|c|c|c|c|c|c|c|c|c|c|}
\hline \multirow{3}{*}{ No } & \multirow{3}{*}{$\begin{array}{c}\text { Asupan } \\
\text { Gizi }\end{array}$} & \multicolumn{4}{|c|}{ Kadar Hb } & \multirow{2}{*}{\multicolumn{2}{|c|}{ Total }} & \multirow{3}{*}{$\mathbf{r}$} & \multirow{3}{*}{$\begin{array}{c}\text { P- } \\
\text { Value }\end{array}$} \\
\hline & & \multicolumn{2}{|c|}{ Normal } & \multicolumn{2}{|c|}{$\begin{array}{c}\text { Anemia } \\
\text { Ringan }\end{array}$} & & & & \\
\hline & & $\mathbf{F}$ & $\%$ & $\mathbf{F}$ & $\%$ & $\mathbf{F}$ & $\%$ & & \\
\hline 1 & Baik & 6 & 85,7 & 1 & 14,3 & 7 & 100 & \multirow{4}{*}{0,411} & \multirow{4}{*}{0.041} \\
\hline 2 & Sedang & 4 & 23,5 & 13 & 76,5 & 17 & 100 & & \\
\hline 3 & Kurang & 1 & 100 & 0 & 0 & 1 & 100 & & \\
\hline 4 & Jumlah & 11 & 113,7 & 14 & 86,5 & 25 & 100 & & \\
\hline
\end{tabular}

Berdasarkan data diatas diketahui bahwa dari 17 responden dengan asupan gizi sedang dan mengalami anemia ringan sebanyak 3 responden $(76,5 \%)$ yang mengalami kadar $\mathrm{Hb}$ normal sebanyak 5 responden $(27,8)$, sedangkan 7 responden dengan asupan gizi baik yang mengalami kadar $\mathrm{Hb}$ normal terdapat 6 responden $(85,7 \%)$ serta yang mengalami anemia ringan 1 responden $(14,3)$. Dan juga terdapat asupan gizi kurang dengan kadar $\mathrm{Hb}$ normal terdapat 1 responden.

Hasil uji statistik diperoleh nilai korelasi 0,411 (korelasi sedang) dan nilai $\mathrm{p}(0,041)$ untuk analisis hubungan antara asupan gizi dengan status gizi ibu hamil, maka dapat dikatakan bahwa Ho ditolak artinya terdapat hubungan yang signifikan antara asupan gizi dengan kadar $\mathrm{Hb}$.

Berdasarkan dari hasil penelitian ibu hamil sebagian besar memiliki asupan gizi yang sedang dikarenakan asupan gizi yang ibu makan tidak seimbang hal ini yang menyebabkan asupan gizi ibu sedang. Sebagian besar ibu hamil dalam setiap harinya mengkonsumsi gizi yang rendah ada juga yang mengkonsumsi seperti junk food, kopi, gorengan yang sebenarnya itu tidak dianjurkan untuk ibu hamil. Dari pengetahuan ibu hamil yang merupakan kehamilan anak pertama, jadi kurangnya pengetahuan ibu tentang gizi yang kurang baik, serta asumsi ibu di masyarakat bahwa makanan yang bergizi itu biasanya merupakan makanan yang mahal memerlukan banyak uang untuk membelinya, padahal tidak semua makanan yang gizinya baik bernilai mahal ada juga makanan yang sederhana, murah dan bernilai murah. Kurang nya pengetahuan ibu tentang makanan yang bervariasi dan makanan yang bagus untuk dikonsumsi pada saat sedang dalam masa kehamilan. Hal ini yang 
menyebabkan asupan gizi ibu hamil kurang.

Apabila ibu mengalami kekurangan gizi selama dalam kehamilan akan menimbulkan masalah, baik pada ibu maupun pada janin yang di kandungnya. Selama hamil, ibu memerlukan gizi yang lebih dibandingkan dengan ibu yang tidak hamil dikarenakan makanan yang dikonsumsi ibu dibutuhkan oleh dirinya dan juga janinnya. Apabila seorang ibu hamil makanannya terbatas maka janin yang ada dalam kandungannya akan tetap menyerap persediaan makanan ibu sehingga ibu menjadi kurus, lemah, pucat, gigi rusak, rambut rontok dan juga akan mempengaruhi tumbuh kembang janin. ${ }^{(3)}$

Berdasarkan dari hasil penelitian disini sebagian besar ibu hamil memiliki kadar $\mathrm{Hb}$ yang $<11$ gr\% atau disebut juga dengan anemia pada ibu hamil, hal ini disebabkan oleh kurangnya pengetahuan ibu hamil dikarenakan ibu hamil yang diteliti primipara otomatis ibu hamil kurang mengetahui asupan yang baik selama dalam menjalani kehamilan dan juga kurangnya pengalaman dalam menjalani kehamilan saat pertama kali. Disebabkan juga karena asupan makanan ibu yang kurang mengandung zat besi di setiap ibu makan, terkadang ada juga ibu yang mengabaikan dalam mengkonsumsi tablet $\mathrm{Fe}$ yang telah diberikan oleh bidan ataupun Puskesmas. bahwasannya status gizi yang buruk merupakan faktor predisposisi terbesar terjadinya anemia, dan penyebab yang paling umum dari anemia pada kehamilan adalah kekurangan zat besi. ${ }^{(4)}$

Anemia dalam kehamilan disebabkan dari kurangnya zat besi, hal ini biasanya disebabkan oleh asupan makanan yang tidak memadai. Ada tiga faktor penting yang menyebabkan seseorang menjadi anemia, yaitu kehilangan darah karena perdarahan akut/kronis, pengrusakan sel darah merah, dan produksi sel darah merah yang tidak cukup banyak. ${ }^{(5)}$

Dari hasil uji korelasi hubungan antara asupan gizi dengan kadar $\mathrm{Hb}$ ibu dapat dilihat bahwa sebagian besar asupan gizi ibu hamil termasuk golongan sedang juga berpengaruh terhadap kadar $\mathrm{Hb}$ ibu hamil yang sebagian besar ibu hamil dengan kadar $\mathrm{Hb}$ yang kurang dari normal atau anemia.

Hasil penelitian ini sejalan dengan hasil penelitian yang dilakukan oleh Nurhidayati A dan Erlyn (2014) tentang asupan nutrisi dengan kadar $\mathrm{Hb}$ ibu hamil di Surakarta bahwa hasil analisis Pearson Product Moment dengan tingkat kepercayaan 5\% diperoleh nilai $r$ hitung $0,674>\mathrm{r}$ tabel 0,312 dan p-value $0.000<0,05$. Hal ini menunjukkan bahwa terdapat hubungan yang signifikan antara asupan nutrisi dengan kadar $\mathrm{Hb}$ pada ibu hamil. Hal ini disebabkan karena kurangnya asupan nutrisi atau intake makanan akan mengakibatkan malnutrisi yang akan mempengaruhi kecepatan pembentukan haemoglobin dan konsentrasi dalam darah menurun sehingga menyebabkan kadar haemoglobin turun. Hal ini terjadi karena zat besi yang tersedia tidak cukup untuk pembentukan hemoglobin, sehingga produksi hemoglobin lebih rendah dari normal, maka memungkinkan untuk terjadinya anemia. ${ }^{(6)}$

Penelitian yang telah dilakukan oleh Sukmaningtyas (2014) tentang tingkat pengetahuan dan status gizi dengan kejadian 
Jurnal Kebidanan Harapan Ibu Pekalongan

anemia juga mengatakan bahwa dari hasil analisis Uji chi-square diperoleh Hasil $p=0,006$ hal ini menunjkan bahwa, ada hubungan antara status gizi dengan kejadian anemia di Puskesmas Gatak Kabupaten Sukoharjo. Hal ini disebabkan karena banyaknya pantangan dan tabu pada ibu hamil sehingga ada makanan tertentu yang tidak boleh dikonsumsi oleh ibu hamil. Semakin kurang baik makanan yang dikonsumsi oleh ibu hamil maka akan semakin tinggi angka kejadian anemia gizi pada ibu hamil. ${ }^{(7)}$

Penelitian yang serupa yang dilakukan oleh Mariana (2018) tentang pola makan dengan kejadian anemia di kota bengkulu juga mengatakan bahwa hasil analisis dengan menggunakan ChiSquare test $\mathrm{p}$-value $=0,035$ menunjukkan ada hubungan antara diet dan kejadian anemia pada ibu hamil. ${ }^{(8)}$

Dalam masa kehamilan sangat memerlukan kebutuhan zat besi, jika persediaan Ferum (Fe) minimal setiap kehamilan akan menguras persediaan $\mathrm{Fe}$ dan akhirnya menimbulkan anemia. Jika intake makanan tidak adekuat, maka besi yang tersedia tidak mencukupi untuk sintesis haemoglobin karena defisiensi besi dalam makanan, walaupun eritrosit tetap diproduksi dalam jumlah biasa akan tetapi kandungannya lebih rendah dari normal dan berukuran lebih kecil sehingga kurang mampu mengangkut oksigen. Dengan demikian semakin sedikit kandungan zat besi yang terkandung dalam makanan kemungkinan terjadinya anemia akan semakin besar.

Nutrisi yang baik adalah cara terbaik untuk mencegah terjadinya anemia untuk ibu hamil yang sangat bermanfaat untuk mendukung proses pertumbuhan organ janin dan pendukung proses kehamilan, serta proses metabolisme zat gizi. Penambahan asupan besi, baik lewat makanan dan/atau pemberian suplemen, terbukti mencegah penurunan $\mathrm{Hb}$ dan diminum setiap hari. ${ }^{(4)}$

Peningkatan energi dan zat gizi diperlukan untuk tumbuh kembang janin, pertambahan besarnya organ kandungan, perubahan komposisi dan metabolisme tubuh ibu selama dalam kehamilan,untuk itu asupan gizi yang baik sangat diperlukan untuk menunjang kesejahteraan ibu dan juga janin yang ada dalam kandungan. Upaya untuk meningkatkan status gizi ibu hamil perlu mengkonsumsi nutrisi yang baik, konsumsi tablet $\mathrm{Fe}$ secara rutin, mengurangi aktivitas yang berlebih, meningkatkan pengetahuan tentang kebutuhan gizi dan nutrisi selama kehamilan.

\section{Kesimpulan}

Sebagian besar ibu hamil trimester III di wilayah UPTD Puskesmas Ciawigebang tahun 2017 memiliki Angka Kecukupan Gizi (AKG) pada derajat yang cukup yaitu 17 orang (68\%). Sebagian besar ibu hamil trimester III di wilayah UPTD Puskesmas Ciawigebang tahun 2017 mengalami anemia ringan terdapat 14 orang (56\%). Terdapat hubungan yang signifikan antara asupan gizi dengan kadar $\mathrm{Hb}$ ibu hamil di wilayah UPTD Puskesmas Ciawigebang Kabupaten Kuningan tahun 2017 dengan nilai $\mathrm{p}(0,041)$ dan memiliki derajat korelasi sedang dengan nilai $r=0,411$. 
Jurnal Kebidanan Harapan Ibu Pekalongan

\section{Daftar pustaka}

[1] Kemenkes RI, Hasil Utama Riskesdas 2018, balitbangkes, 2018.

[2] Hutahaean. S, Perawatan Antenatal. Jakarta: Salemba Medika, 2013.

[3] Sukarni. I, Margareth. ZH, Kehamilan, Persalinan, dan Nifas. Yogyakarta: Nuha Medika, 2013.

[4] Proverawati. A, Buku Ajar Gizi Untuk Kebidanan. Yogyakarta: Nuha Medika, 2009.

[5] Adriani. M. Bambang W, Peranan Gizi Dalam Siklus Kehidupan. Jakarta: Kencana Prenada Media Grup. 2012.

[6] Nurhidayati. A, Erlyn. H, Hubungan Asupan Nutrisi Dengan Kadar Hb Pada Ibu Hamil Di Bps Suratini Suwarno Surakarta. Jurnal KesMaDaSka, Januari 2014.

[7] Sukmaningtyas. D, Raharjo. B, Catur. W. A, (2014), Hubungan Antara Tingkat Pengetahuan Dan Status Gizi Ibu Hamil Dengan Kejadian Anemia Di Puskesmas Gatak Kabupaten Sukoharjo, Program Studi Kesehatan Masyarakat, Fakultas Ilmu Kesehatan Universitas Muhammadiyah Surakarta, 2014.

[8] Mariana. D, Wulandari. D, Padila, Hubungan Pola Makan Dengan Kejadian Anemia Pada Ibu Hamil Di Wilayah Kerja Puskesmas, Jurnal Keperawatan Silampari vol.1, no.2, Juni 2018. 